\title{
Study on the Influence of International Terrorism on China's Foreign Direct Investment
}

\author{
Xi Zhang \\ School of Management, Shanghai University, Shanghai, China \\ Email: zhangxi96@shu.edu.cn
}

How to cite this paper: Zhang, X. (2019) Study on the Influence of International Terrorism on China's Foreign Direct Investment. Open Access Library Journal, 6: e5972.

https://doi.org/10.4236/oalib.1105972

Received: December 2, 2019

Accepted: December 15, 2019

Published: December 18, 2019

Copyright $\odot 2019$ by author(s) and Open Access Library Inc.

This work is licensed under the Creative Commons Attribution International License (CC BY 4.0).

http://creativecommons.org/licenses/by/4.0/

\begin{abstract}
In recent years, there have been frequent international terrorist activities. Needless to say, this presents a great security risk to China's foreign direct investment. This paper explains the current situation of global terrorist activities and China's foreign direct investment, analyzes the harm of terrorist activities to foreign direct investment, and then proposes response measures from the government and enterprise levels.
\end{abstract}

\section{Subject Areas}

Business Finance and Investment, Political Economy

\section{Keywords}

Foreign Direct Investment (OFDI), International Terrorism, Countermeasure

\section{Current Situation of International Terrorism and China's OFDI}

The word "terror" comes from the Latin TERRERE, meaning "fear". Before the 18th century, the main means of terrorism were assassination and poisoning. After World War II, international terrorism really began to take shape. During this period, terrorist activities occurred mainly in colonial, dependent and newly independent nation-states. At present, terrorist activities have affected more than 100 countries to varying degrees. The means of terrorist activities are increasingly diverse, ranging from traditional kidnapping, hostage-taking and assassination to the use of explosions, attacks, hijackings, chemical and biological weapons and cyber terrorism. Due to the different ideologies, national interests and political positions of different countries, governments, experts and scholars have different definitions of international terrorism. Countries and organiza- 
tions around the world have more than 150 definitions of international terrorism. The Global Terrorism Database (GTD) defines terrorism as follows: The threatened or actual use of illegal force and violence by a non-state actor to attain a political, economic, religious, or social goal through fear, coercion, or intimidation [1].

In recent years, terrorist activities are frequent and terrorist organizations are increasingly rampant. The figures show an increase in the number of terrorist attacks around the world between 2001 and 2014, peaked at 16,840 in 2014 [2]. In the following years, the number of terrorist activities was gradually reduced, but still remained at a high level. There is no denying that terrorist activities will continue to be frequent and the number of terrorist attacks will remain high for a long time to come. Second, terrorism has spread around the world. Countries and regions with weak prevention are becoming areas with a high incidence of terrorist activities. Since the Iraq War, the hot spots of global terrorist activities have been spreading, from individual countries in South Asia and the Middle East to a wider region including Africa and Europe.

By the end of 2017, China's stock of foreign direct investment was \$1.8 trillion, be next to the United States to rank 2. China's OFDI stock is distributed in 189 countries (regions) around the world, accounting for $80.8 \%$ of the total number of countries (regions), covering all sectors of the national economy. There are six industries with a stock of hundreds of billions of dollars. At the end of 2017, China's stock of OFDI in countries along “The Belt and Road" was $\$ 154.398$ billion, accounting for 8.5 percent of China's stock of OFDI. Chinese investors made investment in nearly 3000 enterprises in 57 countries along "The Belt and Road", involving 17 industries of national economy. The cumulative investment in that year was $\$ 20.07$ billion, up $31.5 \%$ year on year, accounting for $12.7 \%$ of China's OFDI flow in the same period. In 2017, China's OFDI registered negative growth for the first time, but the trend of internationalization of Chinese enterprises will not change. Especially, under the guidance of "The Belt and Road" strategy, China's OFDI will still maintain a high level in the future. However, according to the global terrorism index (GTI) released by the Australian Institute for Economics and Peace, eight of the top 20 countries in China's OFDI flow were in the medium-high terrorism index in 2017 . Nearly $35 \%$ of the countries along "The Belt and Road" are in the medium-high terrorism index. Four of the six countries with very high terrorism index are member states of "The Belt and Road": Iraq, Afghanistan, Syria and Pakistan. Terrorism in countries along "The Belt and Road" not only exists traditional terrorism caused by the ideological conflict of traditional ethnic groups, but also includes new terrorism, such as extreme religion represented by al-Qaeda [3]. To sum up, China's OFDI activities are faced with a severe risk of terrorism.

\section{The Influence of International Terrorism on OFDI}

\subsection{Threatening the Personal Safety of Employees}

Once the overseas investment projects of enterprises suffer terrorist attacks, the 
employees of enterprises are extremely vulnerable to the harm of terrorists. Given the violence of terrorist activities, almost every terrorist attack causes casualties, sometimes in the hundreds. Employees are the most important assets of company. In the event of a terrorist attack, employees are likely to be detained, kidnapped or even killed, and the company's overseas business activities will inevitably suffer a major blow. Even if terrorist attacks do not cause physical harm to employees, the resulting psychological fear can also affect their work.

\subsection{Causing Property Damage of Multinational Enterprises}

Terrorist activities will cause significant property losses to enterprises' overseas investment projects [4]. In many overseas contracting projects, the terrorists attacked and kidnapped workers at the construction site, forced the construction project to stop. The project was delayed, which greatly affected the profit of the project. In addition to facing the loss of production and business equipment and other property, companies sometimes need to pay employees kidnapped ransom and compensation. Moreover, in order to prevent terrorist activities, enterprises must increase investment in security, hire a large number of security personnel, increase security facilities. This further reduced the profit of the project.

\subsection{Leading to the Failure of Investment}

If the business environment of the host country is very uncertain and terrorist activities are rampant, the security threat will become an important restriction for enterprises to expand overseas. When the risk of terrorism in the host country increases, the probability of serious casualties and property losses due to terrorist attacks will also increase significantly. In order to avoid loss of interests, potential investment enterprises will often adopt wait-and-see approach instead of entering the market of the host country. Chinese companies' overseas projects are focused on the construction of infrastructure and natural resources development. These projects have a large number of employees, who tend to live and work in relatively enclosed locations. Once there is a terrorist attack, it will bring incalculable loss. Therefore, terrorist activities will seriously affect the confidence of enterprises to enter the market of the host country.

\subsection{Discouraging the Subsequent Investment}

The high risk of terrorism means that companies must increase security and insurance costs when investing in host countries. This will greatly increase the operating cost of investment. The huge fees that have to be paid are likely to overwhelm investors, which inevitably discourages companies from investing. In addition, terrorism risk in the host country often causes persistent social panic, which not only aggravates the uncertainty and disturbs the normal economic and social order, but also leads to production contraction and weak consumer demand in the host country, thus reducing its attraction to foreign direct investment [4]. 


\section{Suggestions for Coping with International Terrorism Risk}

From the above discussion, we can see that International terrorism has brought huge risks to the overseas investment of Chinese enterprises, which will not only affect the investment projects of enterprises but also inhibit the subsequent investment. According to the above analysis, this paper proposes countermeasures from the government and enterprise level.

\subsection{Government}

- Establish and perfect the terrorism risk insurance system for overseas investment

Overseas investment insurance is a special insurance of property, it refers to the government of capital-exporting countries underwrites the political risk that the investment in the host country may encounter, and compensates for the political risk within the coverage and the loss of investment property in an effort to protect investors in the host country of investment property safety [5]. Such insurance can greatly mitigate the losses of domestic investors in the event of political risks and coordinate the interests of the governments and investors. Since the September 11th event, the United States has successively passed the Terrorism Risk Insurance Act, the Terrorism Risk Insurance (Extension) Act and the Terrorism Risk Insurance Program Reauthorization Act to perfect its domestic terrorism insurance mechanism. On this basis, terrorism insurance in political risk insurance has developed into an independent insurance [6]. The continuous development and improvement of the terrorist insurance system provides more accurate and direct prevention for the overseas investment of the United States. At present, there is no law on the operation mechanism of terrorism in China. Although China Export \& Credit Insurance Corporation underwrites the risks of war and political violence, the risks of war and political violence lack a detailed explanation of terrorist activities and the scope of terrorist insurance is not clear, which is not conducive for investors to insure. Even if investors purchase insurance, claim for compensation can be difficult. Therefore, the Chinese government urgently needs to learn from the experience of western countries, formulate and improve the insurance system in line with national condition to reduce the losses caused by the risk of terrorism in the process of global expansion.

- Strengthen cooperation with other countries in the field of counter-terrorism The internationalization of terrorist crimes is a common problem faced by all countries in the world. As an international crime, it is far from enough to rely on only one country to combat it. This requires the joint efforts of all countries in the world and extensive international counter-terrorism cooperation. The Chinese government needs to pay attention to the international anti-terrorism work to provide security for the investment and operation activities of Chinese multinational enterprises. First, the government should establish an "international united front against terrorism" with other countries, improve regional information sharing and coordination mechanisms, strengthen the integration and communi- 
cation of intelligence and information resources. In particular, it is necessary to strengthen the construction of anti-terrorism information sharing mechanism with countries along "The Belt and Road" and make it an important part of "The Belt and Road" initiative. Second, the government should make full use of such platforms as Interpol and Shanghai Cooperation Organization to actively plan bilateral and multilateral international cooperation on counter-terrorism. In light of the new situation and new needs in fighting terrorism, the government should work with countries along "The Belt and Road" to promote the establishment of security cooperation mechanisms, further improve relevant mechanisms for various international criminal cooperation in fighting terrorism, and continuously enhance international counter-terrorism cooperation.

\subsection{Enterprises}

- Assess host country's terrorism risk in advance

When conducting overseas expansion activities, most multinational enterprises mainly attach importance to the evaluation of market entry of the host country, focusing on the collection of market size, consumer demand preference and competitor information of the host country, while ignoring the evaluation of political risk of the country. Risk assessment refers to the definition of the possibility, intensity, duration, region and key risk points of risk events, as well as the quantitative analysis of the impact and loss of risk events on people's lives and property after the occurrence of risk events. Before overseas investment, Chinese enterprises must make a comprehensive assessment of the country or region's political system, economic environment, legislation, culture, ethnic and religious issues and the potential risk of terrorism that may arise from them. Chinese companies should incorporate such political risk assessment into their internal management as a proactive business process and institutionalize it. Enterprises operating overseas should avoid countries or regions with unstable political situation and strong anti-china forces, and choose countries with sound laws and stable political situation for investment.

- Establish a sound early warning system and safeguard mechanism

When establishing investment relations with host governments or enterprises, Chinese enterprises should improve the emergency plans for investment cooperation projects. Enterprises can make emergency plans according to the specific security risks that may be encountered in the region and conduct targeted training to improve the ability of emergency response, so as to ensure the safety of employees and property of enterprises in the event of terrorist attacks. Second, enterprises should pay attention to security operation. The enterprise needs to write the security clause into the project contract according to the international practice to clarify the security responsibility of both parties. At the same time, enterprises shall include security input into their own investment costs to ensure that security work has sufficient manpower, material resources and financial resources. Finally, Chinese enterprises should adopt diversified investment strate- 
gies, cooperate with the government or enterprises of the host country or establish a joint venture as far as possible. To some extent, this can reduce the possibility of enterprises encountering terrorist activities.

- Actively take remedial measures after the event

When encountered terrorist activities overseas, enterprises should adhere to the people-oriented principle and put the safety of employees first. In the event of a terrorist attack, the first choice of an enterprise should be to report to the local government and seek help from Chinese embassies and relevant departments in China, so as to timely and properly handle security accidents under guidance and minimize casualties and property losses. When the risk of terrorism seriously threatens the project operation and the personal safety of employees, the enterprise must choose the exit strategy. It is difficult for enterprises to take effective measures at this time. Withdrawing from the host market as soon as possible could avoid further casualties and losses.

\section{Conclusion}

Foreign direct investment is an important way of enterprise internationalization and a key step of enterprise growth and development. However, enterprises are facing more and more serious terrorism risks in the process of OFDI. Terrorist activities often lead to casualties and property losses of enterprises and even directly lead to the failure of investment projects. Therefore, the government should establish and perfect relevant laws and regulations, strengthen anti-terrorism cooperation with the international community, so as to create a peaceful and stable environment for OFDI of Chinese enterprises in the macro level. Enterprises should improve the process of political risk management and take early warning and safeguard measures to prevent the harm caused by terrorist activities to the maximum extent.

\section{Conflicts of Interest}

The authors declare no conflicts of interest regarding the publication of this paper.

\section{References}

[1] Peng, R.X., Zhang, A.B., Yang, T., and Kong, H.F. (2019) Current Situation and Development Trend of Global Terrorism Based on GTD. Computer Applications and Software, 36, 1-5+21.

[2] Wang, Q. and Tian, Y.M. (2018) Analysis of Global Terrorist Activities Based on GTD and Countermeasures of China. Chinese Criminology Review, 2, 87-96.

[3] Wu, D. (2016) Analysis and Response of Terrorism Security Situation Faced by "The Belt and Road" Initiative. Journal of Heilongjiang Administrative Cadre College of Politics and Law, 6, 111-113.

[4] Liu, H.D. and Chen, X.S. (2018) Risk of Terrorism and China's OFDI to Countries along the Belt and Road Initiative. International Forum, 20, 1-9+76.

http://dx.doi.org/10.13549/j.cnki.cn11-3959/d.2018.03.001 
[5] Tian, X.Q. and Huang, Y.F. (2018) Research on Chinese Enterprises' Overseas Investment Insurance System under the Background of the "Belt and Road Initiative". Globalization, 5, 39-48+132. http://dx.doi.org/10.16845/j.cnki.ccieeqqh.2018.05.004

[6] Wang, S.M. (2017) Study on the Legislation of Overseas Investment Terrorism Insurance-American experience and its enlightenment to our country. Studies in Law and Business, 34, 157-164.

http://dx.doi.org/10.16390/j.cnki.issn1672-0393.2017.04.016 